FOLIA HISTORICA CRACOVIENSIA, 20: 2014, s. 65-94

DOI: http://dx.doi.org/10.15633/fhc.650

Bartłomiej Michał Wołyniec

UNIWERSYTET JAGIELLOŃSKI

\title{
Ars bene moriendi biskupa krakowskiego Piotra Tylickiego w świetle Listu Fryderyka Szembeka do Wawrzyńca Gembickiego
}

W roku 1617 w krakowskiej oficynie typograficznej Andrzeja Piotrkowczyka wydany został drukiem utwór zatytułowany O śmierci świętej pamięci Jego Mości X. Piotra Tylickiego krakowskiego biskupa [...] i nabożnym ku niej przygotowaniu jego List do [...] X. Wawrzyńca Gembickiego z Bożej Łaski arcybiskupa gnieźnieńskiego [...]. Jego autorem był krakowski jezuita Fryderyk Szembek (1575-1644), który w pierwotnym zamyśle chciał o śmierci krakowskiego ordynariusza poinformować jedynie przyjaciela zmarłego hierarchy - arcybiskupa gnieźnieńskiego Wawrzyńca Gembickiego (1559-1624). W niedługim jednak czasie list ten na żądanie egzekutorów biskupiego testamentu oraz za wyraźnym dozwoleniem następcy Piotra Tylickiego na stolicy św. Stanisława - Marcina Szyszkowskiego (1554-1630), jak i zakonnych zwierzchników autora został uzupełniony i wydany drukiem ${ }^{1}$.

Opisywany w powyższym dziele biskup krakowski Piotr Tylicki urodził się w 1543 roku w Kowalu koło Włocławka. Był synem tamtejszego wójta Andrzeja de Tylicze in Prussia herbu Lubicz oraz Jadwigi Bilińskiej herbu Rola. W 1558 roku przyszły ordynariusz krakowski rozpoczął studia w Akademii Krakowskiej, których jednak nie ukończył. Za podkanclerstwa Piotra

\footnotetext{
${ }^{1}$ O śmierci świętej pamięci Jego Mości X. Piotra Tylickiego krakowskiego biskupa etc. etc i nabożnym ku niej przygotowaniu jego List do Jaśnie Oświeconego i Najprzewielebniejszego w Chrystusie Ojca i Pana, Jego Mości X. Wawrzyńca Gembickiego z Bożej Łaski arcybiskupa gnieźnieńskiego etc. etc. etc. Pisany od X. Fryderyka Szembeka Societatis Iesu co rychle po śmierci nieboszczykowskiej, a teraz na uroczysty obchód za dusze jego, na żądanie Ich MM. PP. Exekutorów do druku podany, za wyraźnym dozwoleniem Jego M. X. Marcina Szyszkowskiego biskupa krakowskiego i starszych zakonnych, Kraków 1617, w Drukarni Andrzeja Piotrkowczyka [dalej: O śmierci Piotra Tylickiego...], s. 1.
} 
Myszkowskiego (1562-1569) pracował jako podpisek w kancelarii królewskiej. W 1585 roku został sekretarzem wielkim. Godność tę sprawował do roku 1595. W latach 1591-1595 Piotr Tylicki pełnił funkcję referendarza duchownego, a w latach 1598-1605 był podkanclerzym. W trakcie pełnienia wszystkich powyższych funkcji Piotr Tylicki objął pierwsze beneficja kościelne, w tym przede wszystkim kanonie przemyską, sandomierską, warmińską, poznańską i krakowską. Święcenie diakonatu przyszły biskup krakowski przyjął jednak dopiero w 1588 roku. W trzy lata później (1591) wszedł on z kolei do grona prezbiterów ${ }^{2}$.

W 1595 roku Piotr Tylicki został mianowany biskupem chełmińskim i administratorem diecezji pomezańskiej. Królewską nominację ówczesnego referendarza duchownego na to biskupstwo potwierdził 17 sierpnia 1595 roku papież Klemens VIII (1536-1605). Sakrę biskupią nominat otrzymał z rąk biskupa łuckiego Bernarda Maciejowskiego (1548-1608) w katedrze krakowskiej w październiku tegoż roku. 5 czerwca 1600 roku wolą kapituły katedralnej we Fromborku Piotr Tylicki został wybrany biskupem warmińskim. Papieską prekonizację elekt otrzymał 7 października tegoż roku. Ponieważ w tym samym czasie Piotr Tylicki piastował także godność podkanclerzego, rządy w diecezji sprawował w jego imieniu mianowany jej administratorem kantor fromborskiej katedry Jan Pisiński. W 1604 roku przyszły ordynariusz krakowski został przeniesiony na biskupstwo kujawsko-pomorskie, w którym sprawował swoje rządy do początku roku 1607. 15 stycznia tego roku został bowiem mianowany przez papieża Pawła V (1552-1621) biskupem krakowskim. Uroczysty ingres Piotra Tylickiego do katedry na Wawelu odbył się 21 marca 1607 roku. Od

${ }^{2}$ A. Bruździński, Biskup krakowski Piotr Tylicki wobec zakonów w swojej diecezji (1607-1616). „Folia Historica Cracoviensia” T. 10: 2004, s. 50; tenże, Pasterz sprawiedliwy i kraj miłujący. Biskup kujawsko-pomorski Piotr Tylicki (1604-1607). „Zapiski Kujawsko-Dobrzyńskie” T. 22: 2007, s. 75-84; H. J. Karp, Tylicki Piotr (1543-1616). W: Die Bischöfe des Heiligen Römischen Reiches 1448 bis 1648. Ein biographisches Lexikon. Pod red. E. Gatz. Berlin 1996, s. 717; J. Korytkowski, Prałaci $i$ kanonicy katedry metropolitalnej gnieźnieńskiej od roku 1000 aż do dni naszych. T. 4. Gniezno 1883, s. 171-183; T. Oracki, Słownik biograficzny Warmii, Mazur i Powiśla od połowy XV wieku do 1945 roku. Warszawa 1963, s. 294-295; tenże, Stownik biograficzny Warmii, Prus Książęcych i ziemi malborskiej od XV do XVII wieku. T. 2. Olsztyn 1988, s. 192-193; K. R. Prokop, Poczet biskupów krakowskich. Kraków 1999, s. 154-157; B. Przybyszewski, Krótki zarys dziejów diecezji krakowskiej. T. 2: Czasy nowożytne. Kraków 1993, s. 77-83, 164; Słownik biograficzny kapituły warmińskiej. Olsztyn 1996, s. 259; Z. Szostkiewicz, Katalog biskupów obrządku łacińskiego przedrozbiorowej Polski. „Sacrum Poloniae Millennium” T. 1: 1954, s. 575; W. Urban, Wywody szlachectwa kanoników i prałatów krakowskich (1550-1600). „Rocznik Polskiego Towarzystwa Heraldycznego” T. 4: 1999, s. 174. 
tego momentu przez ponad dziewięć lat pasterzował on diecezji św. Stanisława. Zmarł 13 lipca 1616 roku w Krakowie 3 .

Autor omawianego utworu, czyli Fryderyk Szembek, urodził się z kolei w 1575 roku w Krakowie. Studiował na Uniwersytecie Krakowskim oraz w Rzymie (Collegium Romanum), gdzie 2 lutego 1597 roku wstąpił do Towarzystwa Jezusowego. Święcenia kapłańskie przyjął w 1601 roku w Poznaniu. Tam też rozpoczął swoją zakonną karierę. W latach $1602-1603$ był w stolicy Wielkopolski prefektem szkół jezuickich. W 1604 roku został wykładowcą teologii moralnej w kolegium w Lublinie i funkcję tę sprawował do 1609 roku. W tymże roku został skierowany do pracy w Krakowie, gdzie z roczną przerwą aż do 1633 roku był opiekunem kongregacji studenckiej przy kościele św. Barbary. W latach 1626-1627 Fryderyk Szembek był rektorem krakowskiego kościoła św. Piotra i Pawła. W 1633 roku został prepozytem domu profesorów przy kościele św. Barbary w Krakowie. Rok później wyjechał jednak do Torunia, gdzie aż do śmierci pełnił funkcję opiekuna kongregacji studenckiej. Za swojego życia Fryderyk Szembek był ceniony przede wszystkim jako pisarz, w tym w szczególności jako hagiograf. Jezuita był bowiem autorem żywotów: bł. Doroty z Mątowów (1347-1394), bł. Juty z Chełmży (1220-1260) i bł. Jana Łobdowczyka (zm. 1264). W 1627 roku Fryderyk Szembek wydał ponadto odpowiedź na pismo Gratis autorstwa Jana Brożka. Rok później opublikował tłumaczenie utworu Tybet wielkie państwo w Azyey autorstwa portugalskiego jezuity Antonia de Andrade (1580-1634). Zmarł 10 stycznia 1644 roku w Toruniu 4 .

Omawiany poniżej utwór autorstwa Fryderyka Szembeka należy do tzw. pisarstwa artis bene moriendi. Wydawane w tym nurcie książki miały co prawda różne formy, ale łączył je przedmiot poruszanych w nich rozważań. Ogólnie

${ }^{3}$ H. J. Karp, Tylicki Piotr..., s. 717; T. Oracki, Słownik biograficzny Warmii, Mazur i Powiśla..., s. 294-295; tenże, Słownik biograficzny Warmii, Prus Książęcych i ziemi malborskiej..., s. 192-193; K. R. Prokop, Poczet biskupów..., s. 154-157; Z. Szostkiewicz, Katalog biskupów..., s. 575.

${ }^{4}$ Encyklopedia wiedzy o Jezuitach na ziemiach Polski i Litwy 1564-1995. Oprac. L. Grzebień. Kraków 1996, s. 660; J. Łukaszewska-Haberkowa, Pierwsze pokolenie polskich jezuitów w świetle biografii i egzaminów. Kraków 2013, s. 149; S. K. Olczak, Jezuici otrzymujący święcenia $z$ rąk biskupów poznańskich na przełomie XVI-XVII w. „Roczniki Humanistyczne” T. 31: 1983, z. 2, s. 100; F. Paluszkiewicz, Mały słownik jezuitów w Polsce, Warszawa 1995, s. 221; Słownik polskich teologów katolickich. T. 4. Warszawa 1981, s. 273-274. Przez dłuższy czas F. Szembek uznawany był też za autora spisanego anonimowo w 1595 roku diariusza peregrynacji po Italii, Hiszpanii i Portugalii: H. Barycz, Rewizja rewizji, czyli o przedwczesnym pasowaniu jezuity Fryderyka Szembeka na autora omawianego Diariusza podróży włosko-iberyjskiej z 1595 r. „Odrodzenie i Reformacja w Polsce” T. 22: 1977 , s. 233-242. 
rzecz ujmując, były to bowiem zbiory przykładów postaw i myśli o treści ascetycznej, służące do przygotowania człowieka do przyjęcia śmierci. W pierwszej połowie XV wieku powstały trzy wzorcowe dla tego tematu utwory, które z czasem dały początek szerokiemu rozwojowi omawianego gatunku. Autorem pierwszego z nich był kanclerz uniwersytetu paryskiego Jan Gerson (13631429), który ok. 1408 roku napisał dzieło zatytułowane Opusculum tripartitum de praeceptis decalogi, de confessione et de arte moriendi. Drugie z dzieł, którego autorem był Mateusz z Krakowa (1345-1410), powstało mniej więcej w tym samym czasie (1408/1410) i nosiło znamienny tytuł Ars moriendi ex variis scriptuarum sententiis collecta. Trzecim, a zarazem ostatnim z powstałych w XV wieku utworów tego gatunku było napisane przez arcybiskupa Fermo Domenica de Capranica (1400-1458) Speculum artis bene moriendi, które wyszło spod jego pióra ok. 1452 roku. Wśród historiografów trwa do dnia dzisiejszego ożywiona dyskusja na temat autorstwa wymienionych dzieł i ich wzajemnych zależności. Nie ulega jednak wątpliwości, iż opierały się one na XI-wiecznym dziele św. Anzelma z Canterbury Admonitio moriendi. Wiadomo także, iż trzy wspomniane wyżej dzieła stanowiły podstawę do przygotowania wszystkich innych utworów literatury artis bene moriendi w czasach nowożytnych ${ }^{5}$.

Autorami wydawanych w tym okresie w dużej liczbie utworów byli przede wszystkim jezuici. Oczywiście zarówno duchowni diecezjalni, jak i przedstawiciele innych zakonów nie stronili od zaznaczania swej obecności na rynku tego typu literatury popularnej. Niemniej jednak prym w tej dziedzinie wiedli przedstawiciele Towarzystwa Jezusowego ${ }^{6}$. Tworzona przez nich literatura przeznaczona była zarówno dla duchownych, jak dla wiernych świeckich. Częstokroć zdarzało się jednak, iż autorzy już w samym tytule precyzowali, do kogo ich dziełka są adresowane. W omawianych utworach śmierć była przedstawiana przede wszystkim w perspektywie teologiczno-eschatologicznej. Jej swego ro-

${ }^{5}$ K. Bartoszewski, K. Zbiciak, Ars moriendi. W: Encyklopedia katolicka. T. 1. Pod red. F. Gryglewicza, R. Łukaszyka, Z. Sułowskiego. Lublin 1973, kol. 950; Z. Celichowski, Ars moriendi. Rozprawa bibliograficzna. „Rozprawy Wydziału Filologicznego Akademii Umiejętności w Krakowie” T. 17: 1892, s. 143-167; A. Nowicka-Jeżowa, Sarmaci i śmierć. O staropolskiej poezji żałobnej. Warszawa 1992, s. 18-39; B. Rok, Człowiek wobec śmierci w kulturze staropolskiej. Wrocław 1995, s. 15; H. Szabelska, Ars moriendi. W: Słownik sarmatyzmu. Idee, pojęcia, symbole. Pod red. A. Borowskiego. Kraków 2001, s. 15-18; M. Włodarski, Ars moriendi w literaturze polskiej XV i XVI wieku. Kraków 1987 , s. $15,20$.

${ }^{6}$ G. Huszał, Przygotowanie do śmierci w XVII wieku. „Roczniki Humanistyczne” T. 31: 1983, Z. 2, s. 105-151. 
dzaju uzupełnieniem były z kolei różnego rodzaju refleksje, rozważania filozoficzne i pouczenia natury praktycznej. Wydaje się, iż te ostatnie stanowiły podstawę edukacji, jaką w kwestii śmierci i nauczaniu o niej prowadził w tym okresie Kościół katolicki.

„Umarł nam Jego Miłość Xiądz Biskup Krakowski, przyjaciel dawny y uprzejmy Waszej Miłości, a nasz Miłościwy Pan i dobrodziej”. Tymi słowami Fryderyk Szembek rozpoczął pisany 25 sierpnia 1616 roku, a skierowany do arcybiskupa gnieźnieńskiego Wawrzyńca Gembickiego list opisujący ostatnie dni życia i pobożne przygotowanie się do śmierci ordynariusza krakowskiego Piotra Tylickiego'.

W treści omawianego utworu odnajdujemy wymienione wprost przez autora źródła informacji dotyczące opisywanych przez niego wydarzeń. Po pierwsze, i chyba najważniejsze, Fryderyk Szembek był naocznym świadkiem nie tylko dewocyjnych praktyk Piotra Tylickiego, które miały go przygotować na rozstanie się z życiem doczesnym, ale także samego momentu śmierci biskupa, któremu „oczy [...] rękoma [...] niegodnemi zawarł”" Niezmiernie ważnym źródłem tematu były dla Fryderyka Szembeka także rozmowy, jakie prowadził z krakowskim ordynariuszem podczas jego pobytów w Krakowie ${ }^{11}$, a także pisane przez niego i do niego listy, które częściowo zostały wkomponowane w treść utworu ${ }^{12}$.

Początkowo Fryderyk Szembek zamierzał przekazać arcybiskupowi Wawrzyńcowi Gembickiemu jedynie informacje o zdarzeniach, jakie miały miejsce w czasie choroby bezpośrednio poprzedzającej śmierć Piotra Tylickiego. Ostatecznie autor zdecydował jednak, iż w swoim liście opisze także ostatnie trzy lata życia hierarchy. Zaistniałe $\mathrm{w}$ tym okresie wydarzenia miały bowiem zasadniczy wpływ na postawę Piotra Tylickiego w czasie bezpośrednio poprzedzającym jego śmierć. Autor listu wspomina, iż były to „zacne i pamięci godne

7 Tamże; A. Nowicka-Jeżowa, Sarmaci i śmierć..., s. 18-39; B. Rok, Człowiek wobec śmierci..., s. $16-17$.

${ }^{8}$ O śmierci Piotra Tylickiego..., s. 3.

9 Tamże, s. 48.

10 Tamże, s. 4.

${ }^{11}$ Tamże, s. 5: „co mnie z jego rozmów częstych i nabożnych, gdy w Krakowie mieszkiwał, dobrze jest wiadomo".

${ }^{12}$ O śmierci Piotra Tylickiego..., s. 13: „świadectwa dać mogę, a to tak z listów jego własnych, które przez trzy lata przed śmiercią do mnie nie raz z rozmaitych okazji pisywał, których przednie części niżej tu położęe. 
i do zbudowania pospolitego wielce służące postępki”. Stanowiły one także swego rodzaju wstęp do bezpośredniego przygotowania się Piotra Tylickiego na rozstanie się ze światem ${ }^{13}$.

Warto zwrócić uwagę, iż wydany drukiem list zawiera wiele odwołań i cytatów, które z jednej strony tłumaczą pewne praktyki pobożnościowe biskupa, z drugiej zaś podkreślają ich doniosłość. Uwagę czytelnika zwracają przede wszystkim liczne wtrącone do tekstu właściwego fragmenty z pism chrześcijańskich autorów starożytnych, w tym przede wszystkim świętych: Augustyna ${ }^{14}$, Hieronima ${ }^{15}$, Grzegorza ${ }^{16}$, Chryzostoma ${ }^{17}$, Leona ${ }^{18}$ oraz Cypriana $^{19}$. Znaczna liczba cytatów pochodzi także z różnego rodzaju pism św. Bernarda z Clairvaux ${ }^{20}$. Wydaje się, iż właśnie na dziełach tego świętego Fryderyk Szembek oparł pod względem teologicznomoralnym przygotowaną przez siebie relację. Jeżeli chodzi o św. Hieronima, to autor omawianego utworu odwołał się w nim w szczególności do pisanych przez niego listów, przede wszystkim tych, które były adresowane do Heliodora. Fragment jednego z nich stanowi wraz z cytatem z księgi Eklezjastesa swego rodzaju wprowadzenie do lektury dziełka ${ }^{21}$.

Nieco mniejsze znaczenie mają $\mathrm{w}$ utworze wszelkiego rodzaju odwołania do Biblii. W całym dziele autor cytuje bowiem jedynie cztery księgi Starego Testamentu: Ezechiela ${ }^{22}$, Jeremiasza ${ }^{23}$, Koheleta ${ }^{24}$ oraz Przysłów ${ }^{25}$. Swoistym wprowadzeniem do utworu jest umieszczony na odwrocie karty tytułowej cytat z rozdziału 38 księgi Eklezjastesa: „Memor esto iudicii mei, sic enim erit et tuum mihi heri, et tibi hodie" $(38,23)$. Słowom tym towarzyszy fragment zaczerpnięty z jednego ze wspomnianych powyżej listów św. Hieronima do Heliodora ${ }^{26}$. Przyczyny, jakie skłoniły Fryderyka Szembeka do napisania

\footnotetext{
${ }^{13}$ O śmierci Piotra Tylickiego..., s. 5.

14 Tamże, s. 12, 14, 15, 37.

15 Tamże, s. 13, 18, 22, 24, 30, 45, 48.

16 Tamże, s. 26.

17 Tamże, s. 34.

18 Tamże, s. 41.

19 Tamże, s. 25, 34.

${ }_{20}$ Tamże, s. 6, 8, 9, 12, 17, 18, 40, 42.

${ }_{21}$ Tamże, s. 2.

${ }_{22}$ Tamże, s. 24.

23 Tamże, s. 40.

24 Tamże, s. 2.

25 Tamże, s. 5.

26 Tamże, s. 2.
} 
omawianego utworu, a także relacje, jakie łączyły zmarłego biskupa krakowskiego $\mathrm{z}$ arcybiskupem Wawrzyńcem Gembickim, ilustruje z kolei odwołanie do Księgi Przysłów, w której czytamy: „Omni tempore diligit qui amicus est” $(17,17)^{27}$.

Dość osobliwe w kontekście powyższych cytatów wydaje się umieszczone w utworze odwołanie do pism Seneki. Jezuita zwrócił uwagę na dorobek tego rzymskiego autora tylko jeden raz. Miało to miejsce podczas opisywania przez Fryderyka Szembeka właściwej biskupowi Piotrowi Tylickiemu cnoty pokory ${ }^{28}$.

W kontekście powyższych informacji niezmiernie istotne pozostają także zamieszczone $\mathrm{w}$ treści utworu cytaty $\mathrm{z}$ testamentu Piotra Tylickiego ${ }^{29}$, fragmenty jego korespondencji oraz przytaczane przez Fryderyka Szembeka wypowiedzi krakowskiego hierarchy ${ }^{30}$. Co się tyczy przywołanych powyżej listów, to autor wkomponował $\mathrm{w}$ treść swojego utworu cztery skierowane do siebie pisma biskupa. Dwa z nich zostały przez Piotra Tylickiego wysłane z Borzęcina (19 VIII $1614^{31}$ oraz $30 \mathrm{X} 1614$ roku $^{32}$ ), dwa kolejne natomiast z Kielc (18 VII $1614^{33}$ oraz 25 I $\left.1616 \mathrm{roku}^{34}\right)$.

W liście o śmierci biskupa krakowskiego Piotra Tylickiego autorstwa Fryderyka Szembeka tytułowy hierarcha jawi się z jednej strony jako wielki senator, prawdziwy potomek dawnych Polaków i miłośnik ojczyzny. Był on obdarzony wieloma wielkimi i pięknymi przymiotami, które były powszechnie znane mieszkańcom Korony ${ }^{35}$. Hierarcha jest jednak z drugiej strony także dobrodziejem autora omawianego utworu oraz "dawnym i uprzejmym” przyjacielem arcybiskupa gnieźnieńskiego, adresata utworu ${ }^{36}$. Mimo tak wielu zalet i przymiotów w opisanym przez Fryderyka Szembeka trzyletnim okresie życia hierarchy Piotr Tylicki miał wedle autora ćwiczyć się w trzech zasadniczych cnotach. Pierwszą z nich było „wielkie nabożeństwo i takie jakie ma być rzeczy boskich poważanie”, drugą stanowiła „pokora wielka w dostojeństwie tak

\footnotetext{
27 Tamże, s. 5.

${ }_{28}$ Tamże, s. 13.

29 Tamże, s. 4, 9, 17, 28.

${ }^{30}$ Tamże, s. s. $6,7,10,11-12,14,15,18,22,26-27$.

${ }^{31}$ Tamże, s. 19.

32 Tamże, s. 16.

33 Tamże, s. 20.

34 Tamże, s. 27.

35 Tamże, s. 3, 5.

${ }_{36}$ Tamże, s. 3, 4.
} 
wysokim”, trzecią i ostatnią było z kolei „staranie pilne o zbudowanie bliźnich i wystrzeganie się dania onym najmniejszego zgorszenia" ${ }^{37}$.

\section{Cnoty biskupa}

Cnota pierwsza, czyli „wielkie nabożeństwo i takie jakie ma być rzeczy boskich poważanie"

Pierwszą z wymienionych przez Fryderyka Szembeka cnót, w których ćwiczył się biskup Piotr Tylicki, była pobożność. Była to cnota, względem której - jak stwierdził autor listu - „nie skąpa była szczodrobliwa ręka Pańska” ${ }^{8}$. Traktowana jako zewnętrzny przejaw zażyłości łączącej biskupa Piotra Tylickiego z Bogiem pobożność hierarchy wyrażała się $\mathrm{w}$ różnego rodzaju wielopłaszczyznowych postawach. Nie sposób wymienić tutaj wszystkich jej przejawów, które w swoim utworze przytoczył Fryderyk Szembek. Warto jednak zatrzymać się nad kilkoma z nich.

Pierwszym $\mathrm{z}$ wymienionych przez autora utworu przejawów pobożności Piotra Tylickiego był ogromny szacunek, jaki hierarcha okazywał w stosunku do rzeczy boskich. Mając na względzie ich wielkość i niepojętość, miał zwyczaj mówić o nich: „Po ludzku o rzeczach tych mówimy, a majestat on jest [...] niewypowiedziany, niepojęty, o którym wszystko, co mówimy i mówić możemy, nic nie jest w przyrównaniu do niego i do rzeczy ku niemu należnych" ${ }^{39}$. Szacunek okazywany przez biskupa rzeczom boskim widoczny był także w czasie spędzanym przez Piotra Tylickiego na modlitwie, podczas której uważał, „co i z kim na ten czas rozmawiał serdecznie, częstokroć wzdychiwał i łzami się zalewał"40.

Niezwykle pobożne praktyki towarzyszyły Piotrowi Tylickiemu podczas przygotowań do sprawowania mszy świętej, które póki zdrowie mu pozwalało

${ }^{37}$ Tamże, s. 5. Na trzy cnoty (czystość, miłość i pokorę) jako najważniejsze przymioty, które winny towarzyszyć biskupom, wskazuje św. Bernard z Clairvaux: tenże, O obyczajach i obowiązkach biskupów - O miłowaniu Boga i inne traktaty. Oprac. S. Kiełtyka. Poznań 200o, s. 265-270.

${ }^{38}$ O śmierci Piotra Tylickiego..., s. 6.

${ }^{39}$ Tamże.

40 Tamże. 
odprawiał w niedziele i święta. Każdorazowo rozpoczynał je od rozważania słów Dionizego Areopagity ${ }^{41}$ i Teodoreta z Cyru, którzy w swoich dziełach pisali, iż ofiara mszy świętej jest nie tylko „sacrosanctum et augustissimum Sacrificium”, ale także „horrore et reverentia plenissimum” ${ }^{42}$. Aby do sprawowania tak wielkiego aktu móc się przygotować należycie, Piotr Tylicki spędzał około godziny w samotności, w zamkniętym pokoju. W tym czasie odmawiał siedem psalmów pokutnych ${ }^{43}$ oraz oddawał się lekturze czwartej księgi dzieła Tomasza á Kempis O naśladowaniu Chrystusa ${ }^{44}$. Modlitwom tym towarzyszyły właściwe pobożności biskupa westchnienia oraz rzewnie wylewane łzy. Dopóki zdrowie mu pozwalało, wszystkie te praktyki odprawiał, leżąc krzyżem na kobiercu, gdy zaś siły go opuściły, czynił je, klęcząc lub stojąc ${ }^{45}$. Wydaje się, iż w postawie tej Piotr Tylicki realizował słowa czytywanego przez siebie św. Tomasza á Kempis, który pisał: „Kapłan powinien jaśnieć wszystkimi cnotami i dawać ludziom wzór dobrego życia. Kapłan nie powinien wybierać dróg pospolitych, jakie wystarczają innym ludziom, ale sam przestawać $\mathrm{z}$ aniołami w niebie albo z najdoskonalszymi ludźmi na ziemi” ${ }^{46}$.

Fryderyk Szembek zauważył, iż wspomniane przygotowania bardzo nadwątlały siły biskupa, tak że „u ołtarza z trudnością dźwigać go było, gdy klęknął i znaczne na nim zmordowanie, jak po wielkiej jakiej pracy znać było" 47 . Autor omawianego utworu wspomina także, iż kilkakrotnie próbował rozmawiać na ten temat $\mathrm{z}$ hierarchą i czynił starania, aby zmienił on formę swoich praktyk, tak aby nie stanowiły one zbędnego obciążenia jego zdrowia. Starania jezuity okazały się jednak bezskuteczne, bowiem Piotr Tylicki odmówił mu wprowa-

${ }^{41}$ Oczywiście chodzi tutaj o Pseudo-Dionizego Areopagitę.

${ }^{42}$ O śmierci Piotra Tylickiego..., s. 6.

${ }^{43}$ Grupę siedmiu psalmów pokutnych stanowią biblijne psalmy 6 (Błaganie o litość), 32 (Szczęście płynące z odpuszczenia win), 38 (Błaganie nieszczęśliwego grzesznika), 51 (Wezwanie i prośba pokutnika), 102 (Prośba wygnańca), 130 (Z otchłani grzechu ku Bożemu miłosierdziu) oraz 143 (Modlitwa grzesznika). W numeracji Septuaginty są to odpowiednio psalmy 6, 31, 37, 50, 101, 129, 142.

${ }^{44}$ Czwarta księga dzieła Tomasza à Kempis O naśladowaniu Chrystusa poświęcona jest Eucharystii, w tym m.in. godności Najświętszego Sakramentu i stanu kapłańskiego, przygotowaniu do przyjęcia Komunii Świętej, a także o cnocie pobożności osiąganej poprzez pokorę i wyrzeczenie się samego siebie: Tomasz à Kempis, O naśladowaniu Chrystusa. Przeł. A. Kamieńska. Warszawa 1980.

${ }^{45} \mathrm{O}$ śmierci Piotra Tylickiego..., s. 7.

${ }^{46}$ Tamże; Tomasz à Kempis, O naśladowaniu Chrystusa..., s. 215.

${ }^{47}$ O śmierci Piotra Tylickiego..., s. 7. 
dzenia jakichkolwiek zmian w prowadzony przez siebie tryb przygotowania do mszy świętej. Czynione przez siebie praktyki określił i tak jako niedostateczne w stosunku do sprawowanej na ołtarzu ofiary mszy świętej ${ }^{48}$.

Pobożność biskupa Piotra Tylickiego wyrażała się w niezmiernie charakterystycznym dla tego okresu kulcie męki Pańskiej oraz właściwej już hierarsze czci w stosunku do Bożego miłosierdzia ${ }^{49}$. Szczególnym pietyzmem hierarcha otaczał także Najświętszą Maryję Pannę, do której co dnia kierował swoje modlitwy, a w wigilie jej świąt, dla podkreślenia swojego jej oddania, odziewał się w włosiennicę i zachowywał wstrzemięźliwość w spożywaniu pokarmów aż do zachodu słońca ${ }^{50}$. Podobny ascetyczny charakter przybierały religijne praktyki biskupa $\mathrm{w}$ piątki, $\mathrm{w}$ szczególności zaś te, które przypadały $\mathrm{w}$ adwencie, wielkim poście oraz okresie tzw. suchych dni ${ }^{11}$. Każdorazowo biskup odziewał się wówczas w włosiennicę i jadł dopiero wieczorem, gdy zaś był młody - zauważa Fryderyk Szembek - nic w owe dni nie jadał ${ }^{2}$.

Niezmiernie ważną rolę w pobożności biskupa Piotra Tylickiego odgrywał kult świętych oraz relikwii. W szczególny sposób hierarcha polecał się opiece św. Anny oraz swojego osobistego patrona św. Piotra. Kult apostoła znalazł wyraz m.in. w fundacji srebrnej figury świętego przeznaczonej dla katedry krakowskiej, jak i w przekazaniu znacznej kwoty pieniędzy na wykonanie pokrycia dachu jezuickiego kościoła św. św. Piotra i Pawła w Krakowie ${ }^{53}$. Szczere

${ }^{48}$ Tamże. W kwestii pozostania przy prowadzonym przez siebie trybie przygotowania do mszy świętej Piotr Tylicki miał odpowiedzieć Fryderykowi Szembekowi w sposób następujący: „Maleć to wszystko i nędzne by też i najdłuższe przygotowanie nasze, jużem się tak przyuczył, nieci mi nie będzie" - Tamże.

49 O śmierci Piotra Tylickiego..., s. 8-9. Szczególnym efektem kultu Męki Pańskiej była uczyniona przez Piotra Tylickiego fundacja własnego nagrobka. Scena z wyobrażeniem męki Pańskiej znalazła się na miedzianej tablicy w ołtarzu biskupiej kaplicy grobowej, a sam Piotr Tylicki został na nagrobku przedstawiony jako adorujący krzyż: Tamże. Por.: J. J. Kopeć, Męka Pańska w religijnej kulturze polskiego średniowiecza. Studium nad pasyjnymi motywami i tekstami liturgicznymi. Warszawa 1975, s. 345-360; H. D. Wojtyska, Męka Chrystusa w religijności polskiej XVI-XVIII wieku. W: Męka Chrystusa wczoraj i dziś. Pod red. H. D. Wojtyski, J. J. Kopcia. Lublin 1981, s. 61-79.

${ }^{5}$ O śmierci Piotra Tylickiego..., s. 9-10.

${ }^{51} \mathrm{~W}$ tradycji Kościoła Katolickiego są to kwartalne dni postu i modlitwy przypadające w środę, piątek i sobotę, a obchodzone na początku każdej z czterech pór roku. Pierwsze suche dni przypadają zatem po I niedzieli Wielkiego Postu, drugie po niedzieli Zesłania Ducha Świętego, trzecie po święcie Podwyższenia Krzyża Świętego, a czwarte i ostatnie po wspomnieniu św. Łucji.

${ }^{52}$ O śmierci Piotra Tylickiego..., s. 9.

${ }_{53}$ Tamże, s. 10; A. Bruździński, Biskup krakowski Piotr Tylicki wobec zakonów..., s. 51; tenże, „Zakony do ścisłego zachowania reguły doprowadził”. Biskup Piotr Tylicki wobec zakonów w diecezji 
oddanie świętemu patronowi Piotr Tylicki wyrażał także poprzez kult jego relikwii, które otrzymał od biskupa łuckiego Pawła Wołuckiego (1560-1622). Przywiezione przez hierarchę bezpośrednio z Rzymu relikwie św. Piotra (wraz z innymi) były oprawne w szmaragdowo-złoty krzyżyk, który Piotr Tylicki prezentował wszystkim, którzy go odwiedzali, przy czym szczerze dziękował ofiarodawcy za tak wielki i wspaniały dar ${ }^{54}$.

Wśród innych świętych, względem których biskup krakowski żywił szczególny kult, należy wymienić świętych męczenników rzymskich Sykstusa i Krystynę, których relikwie zostały sprowadzone do krakowskiego kościoła św. Barbary przez jezuitów 2 grudnia 1612 roku. Mający wówczas prawie siedemdziesiąt lat hierarcha sam przewodniczył we wspomnianym kościele podniesieniu relikwii obu świętych, do którego zostały one przeniesione w uroczystej procesji z kościoła Mariackiego. „Choć było błoto niemałe i katar nielekki go molestował”, biskup Piotr Tylicki przewodniczył zdążającej wokół krakowskiego rynku procesjis5. Podobny szacunek dla relikwii hierarcha okazał $\mathrm{w}$ trakcie osobistego przewodniczenia podniesieniu doczesnych szczątków św. Szczepana, które do poświęconego temu męczennikowi krakowskiego Kościoła także sprowadzili jezuici ${ }^{56}$. Chcąc, aby pamięć o sprawowanym przez niego kulcie wobec relikwii przetrwała i wiedziały o nim kolejne pokolenia, biskup zdecydował się ponadto, aby wszystko to, co się działo, spisać, opatrzyć swoją pieczęcią i zachować dla potomnościs7.

krakowskiej (1607-1616). W: Klasztor w Kościele średniowiecznym i nowożytnym. Pod red. M. Derwicha, A. Pobóg-Lenartowicz. Warszawa 2010, s. 124; M. Rożek, Katedra krakowska w XVII wieku. Warszawa 1980, s. 204; S. Załęski, Jezuici w Polsce. T. 4, cz. 2: Kolegia i domy założone w pierwszej dobie rząów Zygmunta III. 1588-1608. Kraków 1904, s. 775.

${ }_{54}$ O śmierci Piotra Tylickiego..., s. 10.

${ }_{55}$ Tamże, s. 11; Archiwum Kurii Metropolitalnej w Krakowie, rkps Acta Episcopalia, T. 39, k. 28-30; J. Wielewicki, Dziennik spraw domu zakonnego oo. Jezuitów u św. Barbary w Krakowie. T. 3. Kraków 1889, s. 89; A. Bruździński, Biskup krakowski Piotr Tylicki wobec zakonów..., s. 52; tenże, „Zakony do ścisłego zachowania reguły doprowadził”..., s. 125; L. Grzebień, Kult świętych w diecezji krakowskiej w okresie potrydenckim (na podstawie diariusza J. Wielewickiego). W: Kanonizacje a nowa ewangelizacja. Sympozjum naukowe z okazji 3o-lecia Instytutu Liturgicznego. Kraków 2000, s. 43; M. Rożek, Uroczystości w barokowym Krakowie. Kraków 1976, s. 229.

${ }^{56}$ O śmierci Piotra Tylickiego..., s. 11-12; J. Wielewicki, Dziennik spraw domu zakonnego..., T. 3, s. 89; A. Bruździński, Biskup krakowski Piotr Tylicki wobec zakonów..., s. 52; A. Bruździński, „Zakony do ścisłego zachowania reguły doprowadził”..., s. 125; M. Rożek, Uroczystości w barokowym Krakowie..., s. 229.

57 O śmierci Piotra Tylickiego..., s. 12. 
Odmienne od powyższych przejawów pobożności Piotra Tylickiego były wszelakiego rodzaju wyrazy religijnej postawy hierarchy wynikające z pełnionego przez niego urzędu. $\mathrm{W}$ trakcie sprawowania swojej biskupiej posługi w diecezji chełmińskiej oraz kujawskiej Piotr Tylicki odebrał szereg kościołów $\mathrm{z}$ rąk heretyków. Szczególnie istotna była w tej kwestii rekatolicyzacja kościoła farnego w Toruniu, przy którym hierarcha osadził jezuitów. Z woli biskupa Piotra Kostki, swego poprzednika na chełmińskiej stolicy biskupiej, oddał zakonnikom dom przygotowany dla nich uprzednio przez niego samego oraz chełmińską kapitułę. W przedsięwzięciu tym, które sprawie Bożej i zbawieniu dusz ludzkich służyło, nie oglądał się hierarcha „na żadne tumulty i postrachy, któremi ono heretyckie miasto groziło" ${ }^{8}$. Spełniając wynikające z piastowanych godności obowiązki fundatorskie, hierarcha w dowód swej pobożności oprócz tego rozbudował w rodzinnym Kowalu kościół parafialny ku czci świętych Urszuli i Małgorzaty. Autor omawianego utworu podaje, iż na same jego wzniesienie Piotr Tylicki przeznaczył blisko 14350 złotych, którą to sumę powiększył o fundusz kościoła zapisany przez fundatora na kwotę 10 tys. złotych ${ }^{59}$.

\section{Cnota druga, czyli „pokora wielka w dostojeństwie tak wysokim”}

Drugą z wymienionych przez Fryderyka Szembeka cnót biskupa Piotra Tylickiego była pokora. Cnota ta według przywołanych przez autora utworu doktorów Kościoła jest dwoista. Jej pierwsza warstwa to tzw. pokora wewnętrzna, inaczej zwana serdeczną. Stanowi ona źródło pokory zewnętrznej, która jako taka bez niej istnieć nie może. Poprzez pokorę zewnętrzną pokazujemy to, „co w sercu o sobie samym trzymamy”, poprzez pokorę zewnętrzną nie zabiegamy

${ }^{58}$ Tamże, s. 7-8; Encyklopedia wiedzy o jezuitach..., s. 697-698; T. Glemma, Stosunki kościelne w Toruniu w stuleciu XVI i XVII na tle dziejów kościelnych Prus Królewskich. „Rocznik Towarzystwa Naukowego w Toruniu” T. 42: 1934, s. 121-155; J. K. Kalinowski, Wawrzyniec Gembicki jako biskup chełmiński i pomezańskiej diecezji wieczysty administrator (1600-1610). Toruń 2011, s. 223226; K. Maliszewski, Działalność jezuitów w protestanckim Toruniu u schyłku XVI i w XVII wieku na tle stosunków wyznaniowych w mieście. W: Jezuici w Toruniu. 1596-1996. Materiały konferencji zorganizowanej w Toruniu 17-23 listopada 1996 r. z okazji Jubileuszu 40o-lecia przybycia Jezuitów do miasta. Pod red. K. Maliszewskiego, W. Rozynkowskiego. Toruń 1997, s. 28-54; J. Małłek, Historyczne uwarunkowania sprowadzenia Zakonu Jezuitów do Torunia w 1596 r. W: Jezuici w Toruniu..., s. 20-27; J. Paszenda, Wybór miejsca na fundację dla jezuitów. W: Jezuicka ars historica. Prace ofiarowane Księdzu Profesorowi Ludwikowi Grzebieniowi SJ. Kraków 2001, s. 457.

59 O śmierci Piotra Tylickiego..., s. 8. 
natomiast o uszanowanie i świeckie powagi ${ }^{60}$. Powołując się w powyższej kwestii na św. Hieronima, Fryderyk Szembek stwierdził, iż odbiciem obu warstw pokory był biskup Piotr Tylicki, czego - jak pisze dalej jezuita - przykłady nam zostawił ${ }^{61}$.

„Pokora serca to fundament wszelkiej cnoty i konieczny warunek osiągnięcia zbawienia wiecznego" - pisał św. Tomasz á Kempis ${ }^{62}$. Bez pokory na próżno czci się według niego „imię świętości”. Zewnętrznie okazywana cześć nie jest jakimkolwiek przejawem pobożności, jeżeli we wnętrzu człowieka zabraknie pokory. Człowiek prawdziwie pokorny to ten, który rozważa własne błędy, samego siebie osądza, a w dzień i w nocy opłakuje własne występki. Pokora człowieka widoczna jest także $w$ naśladowaniu i słuchaniu ludzi pobożnych i uczonych, bowiem u nich należy szukać porady i im także należy pozwolić się pouczaćc ${ }^{6}$.

Najważniejszym bodaj przejawem pokory biskupa Piotra Tylickiego było dopuszczanie do swych uszu prawdy. Był w tym względzie różny od wielu panów, tak świeckich, jak i duchownych, którzy uważali „wszystkie swe sprawy za doskonałe" i lubowali się w słuchaniu pochlebstw ${ }^{64}$. Biskup Piotr Tylicki, mimo iż zawsze chciał od swych rozmówców słyszeć prawdę, bardzo się peszył, gdy go zbyt długo komplementowano. Szczególnie mocno drażniło go to $\mathrm{w}$ trakcie składania przez niego jałmużny. Nie pozwolił nigdy, aby którykolwiek z obdarowanych przez niego ludzi w swym dziękowaniu zbyt długo się rozwodzi16 ${ }^{65}$. Teologicznomoralnych podstaw takiej postawy biskupa można szukać zarówno u św. Bernarda z Clairvaux ${ }^{66}$, jak i u św. Hieronima, który w liście do Nepocjana pisał, aby ten strzegł się ubiegać o próżną chwałę u ludzi, gdyż chwała ludzka może się zmienić na obrazę Boga $^{67}$.

60 Tamże, s. 12-13; Bernard z Clairvaux, O obyczajach i obowiązkach biskupów..., s. 274-278, 288-291.

${ }^{61}$ O śmierci Piotra Tylickiego..., s. 13.

${ }^{62}$ Tomasz à Kempis, Pochwała pokory, która jest fundamentem wszelkiej świętości. W: tegoż, Cztery medytacje. Przeł. A. Sulikowski. Kraków 2001, s. 19.

${ }_{63}$ Tamże, s. 20-25.

${ }^{64}$ O śmierci Piotra Tylickiego..., s. 13; Bernard z Clairvaux, O stopniach pokory i pychy. W: O miłowaniu Boga..., s. 91-95.

${ }_{65}$ O śmierci Piotra Tylickiego..., s. 13-14.

${ }^{66}$ Bernard z Clairvaux, O stopniach pokory i pychy..., s. 91-95, 108-109.

${ }^{67}$ List do Nepocjana o życiu kapłańskiem i zakonnem. W: Listy świętego Hieronima do Heliodora i Nepocjana o życiu pustelniczem, kapłańskiem i zakonnem. Oprac. J. Gajkowski. Warszawa 1904, s. 37 . 
Fryderyk Szembek odnotował, iż hierarcha rad był słuchać przede wszystkim tych słów, które mogły być mu pomocą $\mathrm{w}$ „przejrzeniu się $\mathrm{w}$ [swych] postępkach"68. Autor utworu wspomina ponadto, iż sam wielokrotnie był świadkiem próśb biskupa, aby przypominano mu wszelkie rzeczy, które bądź do zbawienia i doskonałości jego własnej, bądź też do sprawowania urzędu biskupiego mogłyby służyć. Za wszelkie przestrogi Piotr Tylicki dziękował i nigdy się za nie nie obrażał ${ }^{69}$.

Ilustrując wzorcowy wręcz przykład biskupiej pokory, jezuita przedłożył w swoim utworze znamienity przykład jej realizacji. Otóż wydarzyło się pewnego razu, iż hierarcha oddał jedno z beneficjów osobie, która na nie wedle powszechnej opinii nie zasługiwała. Część duchowieństwa upomniała zatem biskupa, iż ten przekazał beneficjum w ręce osoby do tego nieodpowiedniej. $\mathrm{Na}$ słowa te biskup nie tylko się nie obraził, ale wręcz bardzo się nimi zmartwił. Zmartwienie jego było zaś tym większe, iż powiedziano mu także w oparciu o „przykłady z poważnych pisarzów”, co na nieroztropnych biskupów czeka po drugiej stronie życia. Uląkłszy się bardzo, Piotr Tylicki czynił od tej pory pilniejsze starania, aby już więcej nie oddać żadnego beneficjum w ręce osoby do tego nieodpowiedniej ${ }^{\circ}$.

Dwa lata przed swoją śmiercią hierarcha kazał sporządzić dla siebie wykaz zasad, którymi winien się kierować, aby w odpowiedni sposób przygotować się na rozstanie ze światem ${ }^{71}$. Autorem przedłożonych biskupowi zasad był Fryderyk Szembek, który w skierowanym do hierarchy liście nakreślił dwie kwestie, na które Piotr Tylicki winien zwrócić uwagę. Uogólniając, można stwierdzić, iż pierwsza z nich dotyczyła życia osobistego hierarchy, druga natomiast odnosiła się do postępowania Piotra Tylickiego jako biskupa. Fryderyk Szembek pisał, iż jako niczym nieróżniący się od innych człowiek hierarcha winien zwrócić uwagę na czyny swojej młodości, zwłaszcza te, które „przy śmierci większe postrachy uczynić mogły”. Jeżeli takowe wydarzenia biskup odnalazłby w swoim życiorysie, winien za nie mocno i szczerze żałować, a także w miarę swoich możliwości uczynić im zadość ${ }^{72}$.

${ }^{68}$ O śmierci Piotra Tylickiego..., s. 14.

${ }_{69}$ Tamże; Bernard z Clairvaux, O stopniach pokory i pychy..., s. 79-82.

7o O śmierci Piotra Tylickiego..., s. 14-15; Bernard z Clairvaux, O obyczajach i obowiązkach biskupów..., s. 258-261.

${ }^{71}$ O śmierci Piotra Tylickiego..., s. 15.

72 Tamże; M. Laterna, Harfa duchowna to jest dziesięć rozdziałów modlitw katolickich [...]. Kraków 1618, s. 786-798, 819-834; S. Cieślak, Marcin Laterna SJ (1552-1598). Działacz kontrreformacyjny. 
Druga z zaprezentowanych przez jezuitę kwestii odnosiła się z kolei do postępowania Piotra Tylickiego jako biskupa, bowiem „z Ich M. XX. Biskupy dwojaki Pan Bóg będzie miał rachunek i jako z ludźmi i jako z Pasterzami tak wielkich trzód owiec swoich”. Jezuita przestrzega zatem hierarchę, aby przygotowując się na sąd Boży, odpowiedział sobie na cztery ważne dla każdego biskupa pytania. Pierwsze $\mathrm{z}$ nich dotyczyło pilności w zachowywaniu i rozkrzewianiu wiary, w tym staraniu o zbawienie powierzonych pasterskiej opiece biskupa owiec. Drugie z pytań odnosiło się z kolei do problemu rozdawnictwa beneficjów. Zgodnie z wytycznymi Fryderyka Szembeka Piotr Tylicki winien się zastanowić, czy wszelkie rozdane przez niego urzędy i godności kościelne trafiły w ręce ludzi godnych, czy też ich rozdawnictwo „raczej ludziom, a nie kościoła i dusz ludzkich potrzebom i pożytkom dogadzało". Trzecie z pytań dotyczyło kwestii wydatków biskupa, przede wszystkim zaś ich celów i sposobów realizacji. Czwarte i ostatnie odnosiło się z kolei do problemu realizacji przez Piotra Tylickiego właściwych jego biskupiej posłudze powinności ${ }^{73}$.

$\mathrm{Na}$ przesłane przez jezuitę porady dobrego przygotowania się na śmierć hierarcha odpisał osobiście z Borzęcina w dniu 30 października 1614 roku. Biskup przekazał $\mathrm{w}$ nim jezuicie podziękowania za przesłany przez niego uprzednio list. Niemniej jednak zauważył także, iż więcej jest rzeczy, na które każdy biskup w swoim życiowym rachunku winien zwrócić uwagę. Warto zauważyć, iż Piotr Tylicki nie spełnił prośby jezuity dotyczącej spalenia pisanego przez niego listu z przestrogami. Hierarcha w przywołanej powyżej odpowiedzi stwierdził, iż pismo jezuity „nie zasłużyło tego tyraństwa, w szkatule będzie, aby go położyć wyjąwszy przed oczy [można], kiedy trzeba”. Opisaną sytuację Fryderyk Szembek podsumowuje stwierdzeniem: „O, dziwna pokoro biskupa tak wielkiego i senatora, daj Boże, by go w tym wiele Panów naśladować chciało, i żeby każdy w swym stanie takich szukał, coby mu prawdę mówili, zapewne by im lekcej i na tym i na drugim świecie bywało"74.

Przykładem pokory Piotra Tylickiego były wedle Fryderyka Szembeka także właściwe hierarsze staropolskie obyczaje. Były one poważne i odzwierciedlały społeczną pozycję biskupa, nie było w nich jednak znać pychy. Podkreślając ten aspekt biskupiej pokory, jezuita przywołał przykład jałmużny, którą Piotr

Kraków 2003, s. 204-219; A. Nowicka-Jeżowa, Pieśni czasu śmierci. Studium z historii duchowości XVI-XVII wieku. Lublin 1992, s. 331-354.

${ }^{73}$ O śmierci Piotra Tylickiego..., s. 15-16.

${ }_{74}$ Tamże, s. 17. 
Tylicki ofiarował znanemu sobie od pewnego czasu szlachcicowi, który dla poratowania swego zdrowia pragnął udać się na zagraniczne leczenie. Otrzymawszy przesłaną mu od biskupa ofiarę, odrzucił ją i otrzymaną kwotę odesłał właścicielowi. Dowiedziawszy się, iż szlachcic ten wzgardził zaoferowaną mu pomocą, biskup „ramiona tylko ścisnąwszy bez żadnej twarzy zmarszczenia i zagniewania rzekł: Posłałem to, co mi [się] posłać zdało, jeśli Pan nie jest tego wdzięczny, cóż czynić?"75.

Kolejnym z zanotowanych przez Fryderyka Szembeka przejawów pokory Piotra Tylickiego była uczyniona przez niego fundacja własnego nagrobka w katedrze na Wawelu. Przyczyną jego wystawienia był raczej istniejący w tej materii zwyczaj niż chęć efektownego upamiętnienia osoby fundatora. Piotr Tylicki bardziej bowiem myślał, jak siebie w cnoty chrześcijańskie, niż swój własny nagrobek ozdobić. Wielu przyganiało hierarsze, iż nagrobek „był nie tak jako było trzeba doskonale i wybornie zrobiony”. W skierowanym do Fryderyka Szembeka, a pisanym z Borzęcina w dniu 19 sierpnia 1616 roku liście biskup odpowiedział na stawiany mu w tej kwestii zarzut, pisał: „na inszym nam kształcie i proporcjej więcej należy, abyśmy nie tak zostawali ludziom w wytwornej jakiej na kamieniu twarzy, jako żebyśmy wzięte od stworzyciela naszego wyobrażenie, niezbrukane i niezmazane przed nim stawili" 76 .

Kontynuując niejako wątek związany $\mathrm{z}$ doczesnym miejscem spoczynku Piotra Tylickiego, autor omawianego utworu zaznaczył, iż hierarcha sam zdecydował w kwestii treści umieszczonej na jego nagrobku inskrypcji epitafijnej ${ }^{77}$. Około dwa tygodnie przed śmiercią hierarcha rozkazał z kolei, aby pochowano go w stroju nader skromnym, wykonanym $\mathrm{z}$ tabinku pospolitego, czyli białego jedwabiu. Fryderyk Szembek perswadował mu, iż dostojeństwo sprawowanego przez niego urzędu wymaga, aby ciało jego, choć już bez duszy, także uczczone było. Po wielu namowach jezuity biskup zgodził się, aby pochowano go w stroju wykonanym $\mathrm{z}$ atłasu lub adamaszku. Zastrzegł jednak, że i w tym przypadku ubiór ma być skromny ${ }^{78}$.

75 Tamże, s. 18; Bernard z Clairvaux, O stopniach pokory i pychy..., s. 82-84; tenże, O obyczajach i obowiązkach biskupów..., s. 261-265.

${ }^{76}$ O śmierci Piotra Tylickiego..., s. 18-19; M. Rożek, Katedra krakowska..., s. 125, 162-165; W. Tatarkiewicz, Nagrobki z figurami klęczącymi. W: Studia renesansowe. T. 1. Warszawa 1856, s. 287-290.

77 O śmierci Piotra Tylickiego..., s. 19-20.

${ }^{78}$ Tamże, s. 21, 44; Bernard z Clairvaux, O obyczajach i obowiązkach biskupów..., s. 261-265. $\mathrm{O}$ wydaniu dyspozycji dotyczących pogrzebu jako elementu artis bene moriendi - M. Rusiecki, 


\section{Cnota trzecia, czyli „staranie pilne o zbudowanie bliźnich i wystrzeganie się dania onym najmniejszego zgorszenia"}

Trzecią cnotą biskupa było staranie się o zbudowanie powierzonych jego pasterskiej trosce owiec. Usiłował bowiem, aby „onym żadnego z siebie pogorszenia nie dawał, ale raczej przykłady jak najlepsze"79.

Wymowną ilustracją dbałości hierarchy o zbudowanie bliźnich było według Fryderyka Szembeka (wynikające także z pobożności) uczestnictwo schorowanego już hierarchy w różnego rodzaju uroczystościach kościelnych i pomniejszych nabożeństwach. Wśród najważniejszych praktyk tego typu jezuita wymienił udział ponad siedemdziesięcioletniego Piotra Tylickiego w procesjach Bożego Ciała, wielkopiątkowych procesjach pokutnych połączonych $\mathrm{z}$ nawiedzaniem grobów ${ }^{80}$ oraz zachowywanie ścisłych postów, mimo iż przepisy prawa kościelnego już mu tego nie nakazywały. Biskup odrzucał przy tym wszelkiego rodzaju sugestie, aby zmienił bardziej odpowiadające młodemu wiekowi zasady, które człowieka schorowanego i w podeszłym wieku przybliżają do kresu życia.

Dbałość biskupa o omawiane kwestie była niezmiernie mocno widoczna w trakcie wspomnianych już powyżej procesji Bożego Ciała. Mimo słabego zdrowia hierarcha bowiem nie tyle uczestniczył, co przewodniczył tej uroczystości. Na zadane przez przyjaciół i domowników pytanie, czy nie mógłby jedynie odprawić mszy w kościele katedralnym i tam też pokłonić się Najświętszemu Sakramentowi, hierarcha odpowiedział, iż w ten sposób może spowodować zgorszenie wiernych. „Prawdać, żeć mi bardziej na siłach do odprawowania processiej schodzi, ale mi bardziej o zbudowanie ludu wszystkiego idzie, który nie wiedząc, żem tak słaby, mógłby się tego pogorszyć, że biskup w Krakowie będąc, do tak wielkiego i uroczystego nabożeństwa nie pomaga" ${ }^{81}$. W powyższej kwestii Piotr Tylicki nie ustąpił nawet w ostatnim roku swojego życia. Nie mogąc wtedy już chodzić o własnych siłach, kazał się nieść, aby przy przygotowanym w rynku ołtarzu mógł oddać Panu Bogu pokłon i powinnościom biskupim zadośćuczynićs ${ }^{82}$.

Obraz śmierci w katechezie Kościoła katolickiego w XVI-XVIII w. W: Wesela, chrzciny i pogrzeby w XVI-XVIII wieku. Kultura życia i śmierci. Pod red. H. Suchojada. Warszawa 2001, s. 295.

79 O śmierci Piotra Tylickiego..., s. 22.

8o Tamże, s. 23.

${ }^{81}$ Tamże.

${ }^{82}$ Tamże. 
Dla ustrzeżenia od zgorszenia powierzonych jego pasterskiej posłudze owiec Piotr Tylicki nie chciał także uczestniczyć „ostatniej przeszłej wieku swego zimy" we mszy w kaplicy dworu biskupiego w Kielcach i udał się w tym celu do tamtejszej kolegiaty. Tam też z powodu zimna, podczas gdy słuchał mszy świętej, dopadł go paraliż, „tak że mu znacznie na oku i władzy jednej strony ciała i mowie znać ono zarażenie było" ${ }^{3}$. Za perswazją przejeżdżającego wówczas przez Kielce wojewody kijowskiego Stanisław Żółkiewskiego (1547-1620) Piotr Tylicki nakazał zawieźć się do Krakowa, „gdzie zdrowie swe cielesne opatrując, około zdrowia dusznego i gotowania się [na] bliską niżeli przedtym śmierć starania czynił" ${ }^{4}$.

Innym przejawem dbałości o zbudowanie bliźnich, w tym wypadku zaś przede wszystkim biskupich przyjaciół i domowników, było zachowywanie przez hierarchę ścisłych postów. Czynił to ze swej pobożności, nawet wbrew woli lekarzy, którzy prosili go, aby ze względu na swój wiek i stan zdrowia odżywiał się w sposób odpowiedni. Wszelkiego rodzaju perswazje zyskały biskupi posłuch dopiero po rozmowie hierarchy z przeorem krakowskich dominikanów o. Erazmem Ronioszewskim oraz kilkoma jezuitami, w tym Fryderykiem Szembekiem ${ }^{85}$.

Tak jak w przypadku procesji Bożego Ciała, w których biskup uczestniczył przede wszystkim z powodu swojego pobytu w Krakowie, z tak też dbał o rozdawnictwo jałmużny w postaci ubrań dla leżących po ulicach ubogich. „Uważając [bowiem] sam z sobą, że się słusznie mógłby był kto z tego zgorszyć, iż przy bytności biskupiej w tym mieście, taką nędzę widać było, dał zaraz kilkadziesiąt sukien uszyć i płócien nakrajać" ${ }^{\prime 6}$. Rozdawnictwem uszytych ubrań zajął się z woli biskupa jego kapelan ksiądz Jan Kaniowski, który przekazał przygotowane $\mathrm{z}$ nakazu hierarchy odzienie przede wszystkim ubogim leżącym na ulicach ${ }^{87}$.

W dbałość o zapobieganie zgorszenia wiernych wpisywała się także działalność biskupa w kwestii ścigania kłamców i oszczerców ${ }^{88}$. Fryderyk Szembek

${ }^{83}$ O śmierci Piotra Tylickiego..., s. 28.

${ }^{84}$ Tamże, s. 29.

${ }^{85}$ Tamże, s. 23-24. Podobnie dopiero za radą wielu teologów biskup Piotr Tylicki zgodził się na badania lekarskie przeprowadzane przez Żyda: tamże, s. 24.

${ }^{86}$ O śmierci Piotra Tylickiego..., s. 28.

${ }^{87}$ Tamże; Bernard z Clairvaux, O stopniach pokory i pychy..., s. 82-84.

${ }^{88}$ Wspomniana cecha ma swoje uzasadnienie w cytowanym powyżej liście Hieronima do Nepocjana, w którym doktor Kościoła pisał: „Strzeż się także, abyś nie miał języka ani ust 
podaje w tej kwestii przykład abominacji biskupa w stosunku zarówno do autora, jak i treści wydanego pod jego nazwiskiem paszkwilu skierowanego przeciw Towarzystwu Jezusowemu. Utworem, o którym tutaj mowa, jest oczywiście wydana po raz pierwszy w 1614 roku Monita Privata autorstwa Hieronima Zahorowskiego (1582-1634). Wydaje się, iż celem autora było nie tyle pomówienie jezuitów, ile wywołane tym zaspokojenie własnej ambicji i rekompensata wydalenia $z$ Towarzystwa ${ }^{89}$. Dowiedziawszy się o powodowanym przez wspomniane pismo zgorszeniu, biskup Piotr Tylicki kazał wezwać do siebie jego autora, którego następnie przekazał pod osąd powołanej przez siebie w tym celu komisji ${ }^{90}$. Podobnie hierarcha postąpił w 1615 roku, kiedy w Krakowie pojawiły się pochodzące najprawdopodobniej z Francji ulotki z paszkwilami na tenże zakon. W tym przypadku biskup także kazał osądzić winnych zaistniałemu zgorszeniu sprawców. Hierarcha pisał o tym w liście skierowanym do Fryderyka Szembeka, który wysłał 25 stycznia 1616 roku z Kielc ${ }^{91}$.

świerzbiących, to jest abyś innych nie obmawiał, ani obmawiających słuchał": List do Nepocjana..., s. 38. Por.: Bernard z Clairvaux, O stopniach pokory i pychy..., s. 111-112, 114-115.

${ }^{89}$ O śmierci Piotra Tylickiego..., s. 25; H. Zahorowski, Monita privata Societatis Iesu. Notobrigae 1612; A. Bruździński, Biskup krakowski Piotr Tylicki wobec zakonów..., s. 52; tenże, „Zakony do ścisłego zachowania reguły doprowadził”..., s. 125; J. M. de Bujanda, Index Librorum Prohibitorum 160o-1966. Montreal-Geneve 2002, s. 954; Zahorowski Hieronim. W: Encyklopedia wiedzy o jezuitach..., s. 777; J. Tazbir, Hieronim Zahorowski zapomniany autor głośnego pamfletu. „Kwartalnik Historyczny" T. 70: 1963, s. 341-361; tenże, Arianie i katolicy. Warszawa 1971, s. 172-202.

9o O śmierci Piotra Tylickiego..., s. 26. W skład powołanej przez biskupa komisji wchodzili: archidiakon krakowski Jan Fox (1598-1636), rektor Akademii Krakowskiej, kanonik krakowski i proboszcz wielicki Sebastian Krupka (zm. 1625) oraz kanonik sądecki i skarbimierski, kaznodzieja katedralny Sebastian Orzeszek „Nuceryn” (1565-1635): Archiwum Kapituły Katedralnej w Krakowie (dalej: AKKK), rkps Libri Archivi, T. 9, k. 209; H. Barycz, Nucerinus Sebastian (15651635). W: Polski słownik biograficzny. T. 23. Pod red. E. Rostworowskiego. Wrocław-Kraków 1978, s. 405-406; A. Bruździński, Biskup krakowski Piotr Tylicki wobec zakonów..., s. 52; L. Hajdukiewicz, Krupka Sebastian (zm. 1625). W: Polski słownik biograficzny. T. 15. Pod red. E. Rostworowskiego. Wrocław 1970, s. 415-416; T. Słowikowski, Fox (Foxius) Jan. W: Polski słownik biograficzny. T. 7. Pod red. W. Konopczyńskiego. Kraków 1958, s. 69-71; L. Stec, Literacki kształt polskich polemik antyjezuickich $z$ lat 1578-1625. Białystok 1968, s. 217-219; J. Tazbir, Literatura antyjezuicka w Polsce. W: Jezuici a kultura polska. Materiały sympozjum z okazji jubileuszu 5oo-lecia urodzin Ignacego Loyoli (1491-1991) i 45o-lecia powstania Towarzystwa Jezusowego (1540-199o), Kraków 15-17 lutego 1991 r. Pod red. L. Grzebienia, S. Obirka. Kraków 1993, s. 320-321.

${ }_{91}$ O śmierci Piotra Tylickiego..., s. 27; AKKK, rkps Acta Actorum, T. 11, k. 324v; J. Wielewicki, Dziennik spraw domu zakonnego..., T. 2, s. 20; tenże, Dziennik spraw domu zakonnego..., T. 3, s. 178; A. Bruździński, Biskup krakowski Piotr Tylicki wobec zakonów..., s. 52; tenże, „Zakony do ścisłego zachowania reguly doprowadził”..., s. 125. 


\section{Opis ostatnich dni życia biskupa}

Opis ostatnich dni życia biskupa Piotra Tylickiego to de facto autorska relacja Fryderyka Szembeka, który towarzyszył sparaliżowanemu hierarsze w ostatnim półroczu jego życia. Krótki przewodnik artis bene moriendi hierarchy jezuita rozpoczął od przedstawienia mającego miejsce w grudniu 1615 roku paraliżu, który dotknął biskupa w trakcie słuchania mszy świętej w kieleckiej kolegia$\mathrm{cie}^{92}$. Nie dziwi, iż jezuita właśnie od tego wydarzenia rozpoczął opis ostatnich dni życia krakowskiego ordynariusza. W świetle staropolskiej pobożności choroba była bowiem swego rodzaju Bożym posłańcem, który przypominał człowiekowi o bliskości śmierci i potrzebie dobrego do niej przygotowania ${ }^{93}$. Najprawdopodobniej z tego też powodu bezpośrednio po wspomnianym wydarzeniu hierarcha za radą Stanisława Żółkiewskiego został przewieziony do Krakowa, „gdzie około zdrowia dusznego i gotowania się na bliską niżeli przed tym śmierć starania czynił"94.

Stanisław Grochowski (1542-1612) w jednym z popularniejszych podręczników artis bene moriendi pisał, iż choroba wiedzie człowieka do uczynków dobrych, do spowiedzi, do pokuty oraz do żalu za grzechy. Niemoc jest znakiem skierowanej ku człowiekowi miłości Boga, przechodzonym przez niego na ziemi czyśćcem oraz stanem, który w swoisty sposób predestynuje dotkniętego nią człowieka do zbawienia. Choroba jako zwiastun zbliżającej się śmierci przypominała i przynaglała do uporządkowania ważnych życiowo spraw, $\mathrm{w}$ tym przede wszystkim do spisania ostatniej woli rozstającego się ze światem człowieka. Powyższe wskazówki, jak się wydaje, nie były obce także biskupowi Piotrowi Tylickiemu, który w trapiącej go chorobie widział swoistego rodzaju dopust Boży ${ }^{95}$. Warto jeszcze wskazać, iż według staropolskich autorów literatury artis bene moriendi choroba była przeznaczona dla tych, którzy do „cier-

${ }_{92}$ O śmierci Piotra Tylickiego..., s. 28. Znaczne pogorszenie się stanu zdrowia sprawiło, iż Piotr Tylicki zamierzał zrezygnować z pełnionego przez siebie urzędu. Różnego rodzaju perswazje skłoniły go jednak do dłuższej refleksji w tej kwestii: tamże, s. 30 .

${ }_{93}$ Ścieżka pobożnego chrześcijanina to jest nauki i przestrogi co potrzebniejsze na poratowanie wszystkich zbawienia pragnacych. Z włoskich scriptów kapłana jednego Societatis Iesu przekładania X. Stanisława Grochowski. Kraków 160o, w drukarni Jakuba Sibeneychera (dalej: Ścieżka pobożnego chrześcijanina... ), s. 44; M. Rusiecki, Obraz śmierci w katechezie Kościoła katolickiego..., s. 295.

${ }_{94}$ O śmierci Piotra Tylickiego..., s. 28.

${ }_{95}^{5}$ Ścieżka pobożnego chrześcijanina..., s. 44-45; M. Rusiecki, Obraz śmierci w katechezie Kościoła katolickiego..., s. 295. 
pienia są sposobniejsi”. Choroba pozwala bowiem „duchowi stwarzać wspaniałe cnoty, które są z cnotą cierpliwości złączone" ${ }^{\prime 6}$. Według Wojciecha z Pakościa choroba nie tylko czyni człowieka lepszym i wspanialszym, ale może z niego uczynić także świętego i doskonałego. Uczy ona bowiem tego, kogo ogarnie, aby wystrzegał się pokus ${ }^{97}$.

Zasadniczym elementem przygotowania do rozstania się ze światem doczesnym była spowiedź. W związku z tym po powrocie do Krakowa hierarcha przywołał do siebie swojego spowiednika. Był nim ksiądz Kacper Sawicki (1552-1620), jeden $\mathrm{z}$ krakowskich jezuitów. Z omawianego utworu dowiadujemy się, iż zakonnik wysłuchał nie tylko generalnej spowiedzi biskupa, ale także pomniejszych aktów żalu i skruchy, jakie ten czynił praktycznie każdego dnia. Spowiedź generalną Piotr Tylicki uczynił „z wielką skruchą, łez wylewaniem i upokarzaniem się przed majestatem Bożym" ${ }^{98}$. Nie inaczej było także w przypadku każdorazowego przystępowania przez niego do sakramentu pokuty. Hierarcha często z żalem wspominał także, iż w czasie kiedy był biskupem kujawskim bez wyraźnej potrzeby pełnił również funkcję prepozyta miechowskiego"9.

Chcąc niejako ulżyć swoim cierpieniom, Piotr Tylicki oddawał się lekturze różnego rodzaju tekstów autorstwa pisarzy chrześcijańskich. Przede wszystkim był to Thesaurus Rerum Indicarum autorstwa jezuity Piotra Iariciusa. Tematem dzieła było rozkrzewianie wiary katolickiej wśród mieszkańców Indii oraz Ameryki, co też bliskie było sercu krakowskiego ordynariusza ${ }^{100}$. Kolejną nie-

${ }^{96}$ Wojciech z Pakościa, Medycyna duchowna dla chorych i bliskich śmierci ludzi chrześcijańskich, a osobliwie zakonnych. $Z$ doktorów świętych pilno zebrana. Poznań 1618, w drukarni Jana Wolraba (dalej: Medycyna duchowna...), k. 2-3; G. Huszał, Przygotowanie do śmierci..., s. 118-121; B. Rok, Człowiek wobec śmierci..., s. 32.

${ }_{97}$ Wojciech z Pakościa, Medycyna duchowa..., s. 12-19; G. Huszał, Przygotowanie do śmierci..., s. 118; B. Rok, Człowiek wobec śmierci..., s. 32.

${ }^{8}$ O śmierci Piotra Tylickiego..., s. 29. Ksiądz Kacper Sawicki był spowiednikiem biskupa Piotra Tylickiego w latach 1612-1616: J. Wielewicki, Dziennik spraw domu zakonnego..., T. 2, s. 280; tenże, Dziennik spraw domu zakonnego..., T. 3, s. 178-179; A. Bruździński, Biskup krakowski Piotr Tylicki wobec zakonów..., s. 53; tenże, "Zakony do ścisłego zachowania reguły doprowadził”..., s. 126; Sawicki Kasper. W: Encyklopedia wiedzy o jezuitach..., s. 602.

${ }_{99}$ O śmierci Piotra Tylickiego..., s. 30.

${ }_{100}$ Tamże, s. 29; J. Morawski, Droga przed Bogiem. Śmierć świętych abo dyspozycja na śmierć dobrą. Nauką S. Teologii, i pobożnemi z Pisma Świętego i z Ojców SS. mianowicie Świętego Augustyna afektami, także SS. umierających przykładami objaśniona naprzód po łacinie, a potym po polsku. Poznań 1698, w drukarni Collegium Societatis Iesu, s. 113; B. Rok, Człowiek wobec śmierci..., s. 49. 
zwykle chętnie czytaną przez Piotra Tylickiego książką było dzieło autorstwa innego jezuity - Franciszka Ksawerego. Powodem znacznego zainteresowania biskupa tym utworem był nie tylko głód wiedzy na temat rozwoju misji jezuickich w Indiach, ale także - a może przede wszystkim - osobiste zawierzenie świętemu zakonnikowi ${ }^{101}$.

Zanoszonym przez biskupa modlitwom towarzyszyła wielka pokora i wylewanie łez. Fryderyk Szembek odnotował, iż „wiele razy słyszeliśmy [go] mówiącego z wielkim nabożeństwem o dobroci Pańskiej [i] wszystkiego się na wolę jego spuszczającego i powtarzającego one słowa: Fiat voluntas Domini, Fiat voluntas Domini, Bonum Dominum habemus"102. W swojej wielkiej pokorze hierarcha prosił otaczających go kapłanów, aby po raz kolejny podpowiedzieli mu dobry sposób przygotowania się na śmierć, bowiem długotrwałe rozmyślania i modlitwy zbyt mocno nadwyrężały jego zdrowie. W odpowiedzi biskup uzyskał zapewnienie, iż równie dobrym sposobem przygotowania się na spotkanie z Bogiem jest jałmużna, która na swój sposób jest także modlitwą. Fryderyk Szembek przekazał w swoim utworze relację, iż mimo że Piotr Tylicki sporządził już testament, to pod wyraźnym natchnieniem przydanych mu wskazań „do pierwszych pia legata, drugie uczynił, aby tym nagradzał wszystkie swe jakiekolwiek mogły być w urzędzie biskupim niedoskonałości” ${ }^{103}$. Kolejno jezuita wymienia w swoim utworze szereg uczynionych przez hierarchę różnego rodzaju fundacji i darowizn, które podsumowuje stwierdzeniem, iż ,więcej by [ich] było , gdyby śmierć ich nie przerwała"104. Jako przykład Fryderyk Szembek podaje czynione przez Piotra Tylickiego zamysły, których przedmiotem był fundusz ze sreber stołowych szacowanych na 10 tys. złotych oraz kwota kolejnych 9 tys. złotych pochodząca z należącego do hierarchy nieznanego bliżej wyderkaftu na Kujawach ${ }^{105}$.

Wśród wszystkich uczynionych przez siebie darowizn i legatów Piotr Tylicki nie zapomniał o zapisaniu osobnej kwoty $\mathrm{z}$ przeznaczeniem na msze święte odprawiane za spokój jego duszy. W tym celu zapisał tysiąc złotych i rozkazał przy tym, aby msze te zostały odprawione zaraz po jego śmierci, nie zaś dopiero po pogrzebie. Uczynił tak za przykładem - przedstawionym mu przez

\footnotetext{
${ }^{101}$ O śmierci Piotra Tylickiego..., s. 29.

${ }_{102}$ Tamże, s. 29-30.

${ }_{103}$ Tamże, s. 31.

${ }_{104}$ Tamże, s. 31-32.

${ }_{105}$ Tamże, s. 34. W stosunku do czynionych przez siebie darowizn Piotr Tylicki miał mówić: „Dla Boga, aby jeszcze roczek, co bym więcej mógł jeszcze za duszę mą z intrat tych dobrego uczynić, jednak ubezpieczcie mię, jeśli w tym pragnieniu życia tą intencją nie grzeszę": tamże, s. 35 .
} 
Fryderyka Szembeka - hiszpańskiego gubernatora Mediolanu ${ }^{106}$, który zapisał na podobny cel znaczną sumę pieniędzy ${ }^{107}$.

5 lipca 1616 roku doszło do znacznego i nagłego pogorszenia się stanu zdrowia Piotra Tylickiego. Fryderyk Szembek podaje, iż we wtorek po święcie Narodzenia NMP, około godziny siedemnastej „przypadła mu ckliwość wielka około serca i duszność, jakoby zaraz miał umrzeć”. Sprowadzeni z kościoła św. Barbary jezuici Fryderyk Szembek i Kacper Sawicki, a także katedralny kaznodzieja ks. Sebastian Orzeszek „Nuceryn” czynili starania o udzielenie hierarsze sakramentów. O ile nie trzeba było namawiać biskupa, aby ten przystąpił do spowiedzi, to trzeba było to uczynić w kwestii ostatniego namaszczenia. Hierarcha ufny był bowiem w zapewnienie medyków, którzy upewnili go kilka dni wcześniej, iż nie widzą „żadnych nowych accidentia”. Dopiero perswazja ks. Sebastiana Orzeszka „Nuceryna” oraz kanonika krakowskiego Andrzeja Łukomskiego skłoniła biskupa do przyjęcia tego sakramentu ${ }^{108}$. Warto zaznaczyć, iż Katechizm Kościoła katolickiego nakazywał udzielać namaszczenia, dopóki „chory ma w sobie rozum zupełny, a dokąd wiarę i nabożeństwo może pokazać"109. Przytoczonym pouczeniem można zatem tłumaczyć reakcję biskupa Piotra Tylickiego, który po wysłuchaniu obszernego tłumaczenia księdza Sebastiana Nuceryna „natychmiast olej święty kazał na się kłaść” ${ }^{110}$. Dopełnieniem czynionych przy umierającym biskupie obrzędów było przyjęcie przez niego, po uprzedniej spowiedzi u księdza Kacpra Sawickiego, przyniesionego przez Fryderyka Szembeka z kościoła św. Franciszka Najświętszego Sakramentu ${ }^{111}$.

Warto wspomnieć, iż Kościół katolicki nauczał, iż sakrament namaszczenia w sposób symboliczny nie tylko usuwał smutek i przywracał radość, ale także usuwał cierpienie i wzmacniał siły duchowe umierającego. Przyjęcie tego sakramentu uzdalniało człowieka do intensywniejszej walki z pokusami i trwogą śmierci. Staropolscy autorzy dzieł teologicznych pisali, iż sakrament

${ }^{106}$ Chodzi tutaj o Pedro Henriqueza de Acevedo hrabiego de Fuentes (1525-1610).

${ }^{107}$ O śmierci Piotra Tylickiego..., s. 34, 44. Ordynowane przez hrabiego de Fuentes msze miały być odprawione w Mediolanie, Loreto, Rzymie oraz w Hiszpanii: tamże, s. 34.

${ }^{108}$ O śmierci Piotra Tylickiego..., s. 35-36.

${ }^{109}$ M. Rusiecki, Obraz śmierci w katechezie Kościoła katolickiego..., s. 296.

${ }^{110}$ O śmierci Piotra Tylickiego..., s. 36; B. Rok, Człowiek wobec śmierci..., s. 47-48; M. Rusiecki, Obraz śmierci w katechezie Kościoła katolickiego..., s. 296.

${ }^{111}$ O śmierci Piotra Tylickiego..., s. 36; K. Richter, M. Probst, H. Plock, Związki namaszczenia chorych $z$ wiatykiem. W: $Z$ pomoca umierajacym. Przyczynki do rozmowy na temat umierania $i$ śmierci. Warszawa 1989, s. 100-103. 
namaszczenia odnawia w przyjmującym go człowieku wesele, otwiera go na Boże miłosierdzie, a także uzdalnia do cierpliwego znoszenia choroby i godnego przyjęcia śmierci ${ }^{112}$.

Od wspomnianego powyżej wtorku ( 5 lipca 1616 roku) aż do północy z piątku na sobotę (8/9 lipca) biskup Piotr Tylicki „ciężkiemi onemi dusznościami zemdlony, nie mogąc jeść ani spać, leżał w ckliwościach rozmaitych"113. Fryderyk Szembek zapisał, iż w tym też czasie hierarcha poczuł nad sobą łaskę Pańską, tak iż „wszystek się do gotowania na Sąd Boży obrócił, o życie to doczesne już więcej nie dbając i w takiej dyspozycji trwał aż do skończenia żywota"114. Wspomnianej nocy za radą jezuity Piotr Tylicki, trzymając w rękach gromnicę, złożył uroczyste wyznanie swojej wiary, po czym przystąpił do odmawiania różnego rodzaju modlitw oraz psalmów. Gdy zabrakło mu jednak ku temu sił, modlił się w swoich myślach słowami, które wypowiadali zgromadzeni wkoło niego domownicy. Na znak swojego uczestnictwa w modlitwie podnosił ku górze trzymaną w rękach świecę, jakoby wraz z nią miały wędrować ku niebu wszystkie wypowiadane słowa ${ }^{115}$.

Tej samej nocy w niejako symboliczny sposób Piotr Tylicki pożegnał się ze wszystkimi zgromadzonymi wkoło niego domownikami i przyjaciółmi. Udzielił im swojego - jak się miało okazać - ostatniego błogosławieństwa i powiedział: „Dominus det vobis spirituum suum sanctum, ut cognoscatis et faciatis eius voluntatem". Po tych słowach wziął w swoje ręce kropidło i pokropił wodą siebie, jak i zgromadzonych przy nim domowników ${ }^{116}$.

Wczesnym rankiem 13 lipca 1616 roku czuwający przy biskupie Fryderyk Szembek zauważył, iż siły hierarchy całkowicie ustawają. Z tego też powodu pod nieobecność ks. Kacpra Sawickiego skierował do Piotra Tylickiego szereg pytań dotyczących czynionego przez niego żalu i pokuty. Jezuita pytał hierarchę o popełnione przez niego grzechy, zarówno w okresie jego młodości, jak i w czasie zasiadania na tronie czterech kolejnych biskupstw. Na koniec Fryderyk Szembek spytał jeszcze biskupa o wszelkie inne niegodne chrześcijanina czyny, które ten popełnił, a z których mógłby być przed Panem

${ }^{112}$ M. Mikołajczyk, Dzieje liturgii sakramentu chorych $w$ Polsce do Rytuału Piotrkowskiego (1631). W: Studia z dziejów liturgii w Polsce. T. 1. Lublin 1976, s. 241-295; M. Rusiecki, Obraz śmierci $w$ katechezie Kościoła katolickiego..., s. 296-297 (tam dotycząca tematu staropolska literatura teologiczna).

${ }^{113}$ O śmierci Piotra Tylickiego..., s. 37.

${ }_{114}$ Tamże.

115 Tamże, s. 37-38.

${ }^{116}$ Tamże, s. 39; M. Rusiecki, Obraz śmierci w katechezie Kościoła katolickiego..., s. 298. 
Bogiem sądzony. Po otrzymaniu ostatniego w swoim życiu rozgrzeszenia hierarcha ucałował podany mu krucyfiks i rzewnie płacząc, oddał się modlitwie ${ }^{117}$. W trakcie odmawiania litanii do Najświętszej Marii Panny „trzykroć leciuchno ziewnąwszy bez żadnego znaku lękania się, stęknienia albo ciała wzruszenia spokojniusieńko ducha swego twórcy swemu oddał i odszedł od nas na drugi świat właśnie pod ten czas, gdy tu na naszym słońce wschodziło we środę dnia 13 lipca w święto dziewice i męczennice Chrystusowej św. Małgorzaty, której on wespół ze świętą Dorotą Kościół był w Kowalu [...] zbudował"118.

Kończąc powyższe rozważania i jednocześnie próbując podsumować życie biskupa Piotra Tylickiego, należy powtórzyć umieszczoną pod koniec omawianego dzieła prośbę-pochwałę. Fryderyk Szembek tak pisał w niej o zmarłym hierarsze: „Daj nam Boże wiele tak mądrych i ojczyznę szczerze miłujących senatorów, a takie przykłady po sobie zostawiających biskupów x. Piotra Tylickiego naśladujących. [...] Bez pochlebstwa zda mi się rzec o nim może, że to jego przygotowanie na drugi świat przez dobre uczynki, jałmużny i fundacje poczynione z jałmużnami i fundacjami wielkich onych Zbigniewów, Grotów, Iwonów, którzy jako świece jasne z katedry tej Kościoła Krakowskiego nie tylko Koronie, ale wszystkiemu Kościołowi Bożemu postępkami swemi świecili, równać się może”11.

\section{Streszczenie}

Ars bene moriendi biskupa krakowskiego Piotra Tylickiego w świetle Listu Fryderyka Szembeka do Wawrzyńca Gembickiego

W 1617 roku w krakowskiej oficynie wydawniczej Andrzeja Piotrkowczyka wydany został drukiem utwór zatytułowany O śmierci świętej pamięci Jego Mości X. Piotra Tylickiego

${ }_{117}$ O śmierci Piotra Tylickiego..., s. 42; B. Rok, Człowiek wobec śmierci..., s. 48.

${ }^{118}$ O śmierci Piotra Tylickiego..., s. 43; Szembek pomylił patronki tego kościoła - nosił on wezwanie św. Urszuli, a nie Doroty.

${ }^{119}$ Tamże, s. 45. 
krakowskiego biskupa [...] i nabożnym ku niej przygotowaniu jego List do [...] X. Wawrzyńca Gembickiego z Bożej Łaski arcybiskupa gnieźnieńskiego [...]. Jego autorem był krakowski jezuita Fryderyk Szembek (1575-1644), który w pierwotnym zamyśle chciał o śmierci krakowskiego ordynariusza poinformować jedynie przyjaciela zmarłego hierarchy - arcybiskupa gnieźnieńskiego Wawrzyńca Gembickiego (1559-1624). W niedługim jednak czasie list ten na żądanie egzekutorów biskupiego testamentu oraz za wyraźnym dozwoleniem następcy Piotra Tylickiego na stolicy św. Stanisława Marcina Szyszkowskiego (1554-1630), jak i zakonnych zwierzchników autora został uzupełniony i wydany drukiem.

Omawiany poniżej utwór autorstwa Fryderyka Szembeka należy do tzw. pisarstwa artis bene moriendi. Wydawane w tym nurcie książki miały co prawda różne formy, łączył je jednak przedmiot poruszanych w nich rozważań. Ogólnie rzecz ujmując, były to zbiory przykładów postaw i myśli o treści ascetycznej, służące do przygotowania człowieka na przyjęcie śmierci.

Tytułowy biskup został w utworze przedstawiony z jednej strony jako wielki senator, prawdziwy potomek dawnych Polaków i miłośnik ojczyzny. Z drugiej zaś Piotr Tylicki był także dobrodziejem autora utworu oraz „dawnym i uprzejmym” przyjacielem adresata listu - arcybiskupa gnieźnieńskiego. Mimo tak wielu zalet i przymiotów w opisanym przez Fryderyka Szembeka trzyletnim okresie życia hierarchy Piotr Tylicki miał wedle autora ćwiczyć się w trzech zasadniczych cnotach. Pierwszą z nich było „wielkie nabożeństwo i takie, jakie ma być rzeczy boskich poważanie”, drugą stanowiła „pokora wielka w dostojeństwie tak wysokim”, trzecią i ostatnią było z kolei „staranie pilne o zbudowanie bliźnich i wystrzeganie się dania onym najmniejszego zgorszenia”.

Słowa kluczowe

Piotr Tylicki, biskup krakowski, XVII wiek, Fryderyk Szembek, sztuka umierania (ars moriendi)

\section{Summary}

\section{Ars bene moriendi of Piotr Tylicki bishop of Cracow in the Letter of Fryderyk Szembek to Wawrzyniec Gembicki.}

In the year 1617 in Cracow printer Andrzej Piotrowczyk published book under the title O śmierci świętej pamięci Jego Mości X. Piotra Tylickiego krakowskiego biskupa [...] 
i nabożnym ku niej przygotowaniu jego List do [...] X. Wawrzyńca Gembickiego z Bożej Łaski arcybiskupa gnieźnieńskiego [...]. Author of this work was one of the Cracow's Jesuits Fryderyk Szembek (1575-1644). He wrote his letter to informed about death of bishop Piotr Tylicki to archbishop of Gniezno Wawrzyniec Gembicki (1559-1624), who was friend of dead. This work was however published in the short time, as it was mentioned, because of decision of executors of the bishop's Piotr Tylicki will, religious superiors to Fryderyk Szembek and new bishop of Cracow, Marcin Szyszkowski (1554-1630).

Szembek's letter is example of ars bene moriendi writings. This type of literature have different forms, but all of them prepare men to the death. Therefore, they contain examples of attitudes and thoughts for dying person.

Bishop Piotr Tylicki was presented in this letter as a exemplary senator, descendant of the nobles and patriot who loved his motherland, Poland. Bishop however had practiced his virtues. Those included religiosity, humility and care of piety of others. On the other hand we have to remember that, he was also the tutor of author. What is more, archbishop of Gniezno, as it was mentioned, was "old and kind” friend of bishop Piotr Tylicki.

\section{Keywords}

Piotr Tylicki, bishop of Cracow, $17^{\text {th }}$ century, Fryderyk Szembek, The Art of Daying (ars moriendi)

\section{Bibliografia}

\section{Źródła rękopiśmienne}

Archiwum Kapituły Katedralnej w Krakowie, rkps Libri Archivi, T. 9.

Archiwum Kurii Metropolitalnej w Krakowie, rkps Acta Episcopalia, T. 39.

\section{Źródła drukowane}

Bernard z Clairvaux, O miłowaniu Boga i inne traktaty. Oprac. S. Kiełtyka. Poznań 2000. J. Morawski, Droga przed Bogiem. Śmierć świętych abo dyspozycja na śmierć dobra. Nauka S. Teologii, i pobożnemi z Pisma Świętego i z Ojców SS. mianowicie Świętego Augustyna afektami, także SS. umierających przykładami objaśniona naprzód po łacinie, a potym po polsku. Poznań 1698, w drukarni Collegium Societatis Iesu.

Listy świętego Hieronima do Heliodora i Nepocjana o życiu pustelniczem, kapłańskiem i zakonnem. Oprac. J. Gajkowski. Warszawa 1904.

M. Laterna, Harfa duchowna to jest dziesięć rozdziałów modlitw katolickich z rozlicznych Kościoła Powszechnego Doktorów y z Rzymskich Mszałow y Brewiarzow po wielkiey części zebranych. Przydano do każdego rozdziału Nauki o tych rzeczach, które się w Modlitwach zamykaia a na niektórych mieścach wykładem y przypiskami psalmy y modlitwy objaśnione. Kraków 1618, w drukarni Andrzeja Piotrkowczyka. 
O śmierci świętej pamięci Jego Mości X. Piotra Tylickiego krakowskiego biskupa etc. etc i nabożnym ku niej przygotowaniu jego List do Jaśnie Oświeconego i Najprzewielebniejszego w Chrystusie Ojca i Pana, Jego Mości X. Wawrzyńca Gembickiego z Bożej Łaski arcybiskupa gnieźnieńskiego etc. etc. etc. Pisany od X. Fryderyka Szembeka Societatis Iesu co rychle po śmierci nieboszczykowskiej, a teraz na uroczysty obchód za duszę jego, na żądanie Ich MM. PP. Exekutorów do druku podany, za wyraźnym dozwoleniem Jego M. X. Marcina Szyszkowskiego biskupa krakowskiego i starszych zakonnych. Kraków 1617, w drukarni Andrzeja Piotrkowczyka.

Ścieżka pobożnego chrześcijanina to jest nauki i przestrogi co potrzebniejsze na poratowanie wszystkich zbawienia pragnących. $Z$ włoskich scriptów kapłana jednego Societatis Iesu przekładania X. Stanisława Grochowskiego. Kraków 1600, w drukarni Jakuba Sibeneychera.

Tomasz à Kempis, O naśladowaniu Chrystusa. Przeł. A. Kamieńska. Warszawa 1980.

Tomasz à Kempis, Pochwała pokory, która jest fundamentem wszelkiej świętości. W: tegoż, Cztery medytacje. Przeł. A. Sulikowski. Kraków 2001.

Wielewicki J., Dziennik spraw domu zakonnego oo. Jezuitów u św. Barbary w Krakowie. T. 3. Kraków 1889.

Wojciech z Pakościa, Medycyna duchowna dla chorych i bliskich śmierci ludzi chrześcijańskich, a osobliwie zakonnych. $Z$ doktorów świętych pilno zebrana. Poznań 1618, w drukarni Jana Wolraba.

\section{Opracowania}

Bartoszewski K., Zbiciak K., Ars moriendi. W: Encyklopedia katolicka. T. 1. Pod red. F. Gryglewicza, R. Łukaszyka, Z. Sułowskiego. Lublin 1973, kol. 950.

Barycz H., Nucerinus Sebastian (1565-1635). W: Polski słownik biograficzny. T. 23. Pod red. E. Rostworowskiego. Wrocław-Kraków 1978, s. 405-406.

Barycz H., Rewizja rewizji, czyli o przedwczesnym pasowaniu jezuity Fryderyka Szembeka na autora omawianego Diariusza podróży włosko-iberyjskiej z 1595 r. „Odrodzenie i Reformacja w Polsce" T. 22: 1977, s. 233-242.

Bruździński A., „Zakony do ścisłego zachowania reguły doprowadził”. Biskup Piotr Tylicki wobec zakonów $w$ diecezji krakowskiej (1607-1616). W: Klasztor w Kościele średniowiecznym i nowożytnym. Pod red. M. Derwicha, A. Pobóg-Lenartowicz. Warszawa 2010, s. 121-142.

Bruździński A., Biskup krakowski Piotr Tylicki wobec zakonów w swojej diecezji (16071616). „Folia Historica Cracoviensia” T. 10: 2004, s. 49-69.

Bruździński A., Pasterz sprawiedliwy i kraj miłujący. Biskup kujawsko-pomorski Piotr Tylicki (1604-1607). „Zapiski Kujawsko-Dobrzyńskie” T. 22: 2007, s. 75-84.

Bujanda de J. M., Index Librorum Prohibitorum 1600-1966. Montreal-Geneve 2002.

Celichowski Z., Ars moriendi. Rozprawa bibliograficzna. „Rozprawy Wydziału Filologicznego Akademii Umiejętności w Krakowie” T. 17: 1892, s. 143-167.

Cieślak S., Marcin Laterna SJ (1552-1598). Działacz kontrreformacyjny. Kraków 2003. 
Encyklopedia wiedzy o Jezuitach na ziemiach Polski i Litwy 1564-1995. Oprac. L. Grzebień. Kraków 1996.

Glemma T., Stosunki kościelne w Toruniu w stuleciu XVI i XVII na tle dziejów kościelnych Prus Królewskich. „Rocznik Towarzystwa Naukowego w Toruniu” T. 42: 1934, s. 121-155.

Grzebień L., Kult świętych $w$ diecezji krakowskiej w okresie potrydenckim (na podstawie diariusza J. Wielewickiego). W: Kanonizacje a nowa ewangelizacja. Sympozjum naukowe z okazji 3o-lecia Instytutu Liturgicznego. Kraków 200o, s. 31-45.

Hajdukiewicz L., Krupka Sebastian (zm. 1625). W: Polski słownik biograficzny. T. 15. Pod red. E. Rostworowskiego. Wrocław 1970, s. 415-416.

Huszał G., Przygotowanie do śmierci w XVII wieku. „Roczniki Humanistyczne” T. 31: 1983, z. 2, s. 105-151.

Kalinowski J. K., Wawrzyniec Gembicki jako biskup chetmiński i pomezańskiej diecezji wieczysty administrator (1600-1610). Toruń 2011.

Karp H. J., Tylicki Piotr (1543-1616). W: Die Bischöfe des Heiligen Römischen Reiches 1448 bis 1648. Ein biographisches Lexikon. Pod red. E. Gatz. Berlin 1996, s. 717.

Kopeć J. J., Męka Pańska w religijnej kulturze polskiego średniowiecza. Studium nad pasyjnymi motywami i tekstami liturgicznymi. Warszawa 1975, s. 345-36o.

Korytkowski J., Prałaci i kanonicy katedry metropolitalnej gnieźnieńskiej od roku 1000 aż do dni naszych. T. 4. Gniezno 1883.

Łukaszewska-Haberkowa J., Pierwsze pokolenie polskich jezuitów w świetle biografii i egzaminów. Kraków 2013.

Maliszewski K., Działalność jezuitów w protestanckim Toruniu u schyłku XVI i w XVII wieku na tle stosunków wyznaniowych $w$ mieście. W: Jezuici w Toruniu. 1596-1996. Materiały konferencji zorganizowanej $w$ Toruniu 17-23 listopada 1996 r. $z$ okazji Jubileuszu 40o-lecia przybycia Jezuitów do miasta. Pod red. K. Maliszewskiego, W. Rozynkowskiego. Toruń 1997, s. 28-54.

Małłek J., Historyczne uwarunkowania sprowadzenia Zakonu Jezuitów do Torunia w 1596 r. W: Jezuici w Toruniu. 1596-1996. Materiały konferencji zorganizowanej w Toruniu 17-23 listopada 1996 r. z okazji Jubileuszu 40o-lecia przybycia Jezuitów do miasta. Pod red. K. Maliszewskiego, W. Rozynkowskiego. Toruń 1997, s. 20-27.

Mikołajczyk M., Dzieje liturgii sakramentu chorych $w$ Polsce do Rytuału Piotrkowskiego (1631). W: Studia z dziejów liturgii w Polsce. T. 1. Lublin 1976, s. 241-295.

Nowicka-Jeżowa A., Pieśni czasu śmierci. Studium z historii duchowości XVI-XVII wieku. Lublin 1992.

Nowicka-Jeżowa A., Sarmaci i śmierć. O staropolskiej poezji żałobnej. Warszawa 1992.

Olczak S. K., Jezuici otrzymujący święcenia $z$ rąk biskupów poznańskich na przełomie XVI-XVII w. „Roczniki Humanistyczne” T. 31: 1983, z. 2, s. 85-104.

Oracki T., Słownik biograficzny Warmii, Mazur i Powiśla od połowy XV wieku do 1945 roku. Warszawa 1963.

Oracki T., Słownik biograficzny Warmii, Prus Książęcych i ziemi malborskiej od XV do XVII wieku. T. 2. Olsztyn 1988. 
Paluszkiewicz F., Mały słownik jezuitów w Polsce, Warszawa 1995.

Paszenda J., Wybór miejsca na fundację dla jezuitów. W: Jezuicka ars historica. Prace ofiarowane Księdzu Profesorowi Ludwikowi Grzebieniowi SJ. Kraków 2001, s. 453-467.

Prokop K. R., Poczet biskupów krakowskich. Kraków 1999.

Przybyszewski B., Krótki zarys dziejów diecezji krakowskiej. T. 2: Czasy nowożytne. Kraków 1993.

Richter K., Probst M., Plock H., Związki namaszczenia chorych z wiatykiem. W: Z pomoca umierajacym. Przyczynki do rozmowy na temat umierania i śmierci. Warszawa 1989, s. 100-103.

Rok B., Człowiek wobec śmierci w kulturze staropolskiej. Wrocław 1995.

Rożek M., Katedra krakowska w XVII wieku. Warszawa 1980.

Rożek M., Uroczystości w barokowym Krakowie. Kraków 1976.

Rusiecki M., Obraz śmierci w katechezie Kościoła katolickiego w XVI-XVIII w. W: Wesela, chrzciny i pogrzeby w XVI-XVIII wieku. Kultura życia i śmierci. Pod red. H. Suchojada. Warszawa 2001, s. 287-302.

Słowikowski T., Fox (Foxius) Jan. W: Polski słownik biograficzny. T. 7. Pod red. W. Konopczyńskiego. Kraków 1958, s. 69-71.

Słownik biograficzny kapituły warmińskiej. Pod red. J. Guzowskiego, Olsztyn 1996.

Słownik polskich teologów katolickich. Pod red. H. E. Wyczawskiego. T. 4. Warszawa 1981. Stec L., Literacki kształt polskich polemik antyjezuickich z lat 1578-1625. Białystok 1968.

Szabelska H., Ars moriendi. W: Słownik sarmatyzmu. Idee, pojęcia, symbole. Pod red. A. Borowskiego. Kraków 2001, s. 15-18.

Szostkiewicz Z., Katalog biskupów obrządku łacińskiego przedrozbiorowej Polski. „Sacrum Poloniae Millennium" T. 1: 1954, s. 391-619.

Tatarkiewicz W., Nagrobki z figurami klęczacymi. W: Studia renesansowe. T. 1. Warszawa 1956, s. 274-328.

Tazbir J., Arianie i katolicy. Warszawa 1971.

Tazbir J., Hieronim Zahorowski zapomniany autor głośnego pamfletu. „Kwartalnik Historyczny" T. 70: 1963, s. 341-361.

Tazbir J., Literatura antyjezuicka $w$ Polsce. W: Jezuici a kultura polska. Materiały sympozjum z okazji jubileuszu 50o-lecia urodzin Ignacego Loyoli (1491-1991) i 450-lecia powstania Towarzystwa Jezusowego (1540-199o), Kraków 15-17 lutego 1991 r. Pod red. L. Grzebienia, S. Obirka. Kraków 1993, s. 311-333.

Urban W., Wywody szlachectwa kanoników i prałatów krakowskich (1550-160o). „Rocznik Polskiego Towarzystwa Heraldycznego" T. 4: 1999, s. 165-176.

Włodarski M., Ars moriendi w literaturze polskiej XV i XVI wieku. Kraków 1987.

Wojtyska H. D., Męka Chrystusa w religijności polskiej XVI-XVIII wieku. W: Męka Chrystusa wczoraj i dziś. Pod red. H. D. Wojtyski, J. J. Kopcia. Lublin 1981, s. 61-79.

Załęski S., Jezuici w Polsce. T. 4, cz. 2: Kolegia i domy założone w pierwszej dobie rządów Zygmunta III. 1588-1608. Kraków 1904. 